\title{
PENGARUH STRUKTUR MODAL DAN PROFITABILITAS TERHADAP NILAI PERUSAHAAN PADA PT. KALBE FARMA, Tbk.
}

\author{
Muhibah $^{1}$, Andi Rifqah Purnama Alam ${ }^{2}$ \\ STIE Tri Dharma Nusantara ${ }^{1,2}$ \\ Email : muhibah.stietdn@gmail.com ${ }^{1}$, emailnya.pitta@gmail.com ${ }^{2}$
}

\begin{abstract}
Abstrak
Penelitian ini bertujuan untuk mengetahui pengaruh struktur modal (DER) dan profitabilitas (ROA) terhadap nilai perusahaan (PBV) pada PT. Kalbe Farma, Tbk Penelitian ini menggunakan data kuantitatif. Sumber data yang digunakan yaitu data sekunder. Metode analisis yang digunakan adalah analisis regresi berganda, koefisien korelasi (r) dan koefisien determinasi $\left(\mathrm{r}^{2}\right)$, uji-t dan uji f.. Hasil penelitian menunjukkan bahwa secara parsial struktur modal (DER) berpengaruh negatif dan tidak signifikan terhadap nilai perusahaan, (PBV) sedangkan profitabilitas (ROA) berpengaruh positif dan tidak signifikan terhadap nilai perusahaan (PBV). Secara simultan, struktur modal (DER) dan profitabilitas berpengaruh tidak signifikan terhadap nilai perusahaan (PBV). Berdasarkan hasil koefisien determinasi sebesar 0,36 berarti nilai perusahaan (PBV) dipengaruhi oleh strukturr modal (DER) dan profitabilitas (ROA) sebesar 36\% dan sisanya $64 \%$ dipengaruhi oleh faktor lain yang tidak diteliti. Hipotesis dalam penelitian ini diterima.
\end{abstract}

Kata kunci : struktur modal, profitabilitas, nilai perusahaan

\section{Abstract}

This study aims to determine the effect of capital structure (DER) and profitability (ROA) on firm value (PBV) at PT. Kalbe Farma, Tbk This research uses qualitative data and quantitative data. The data source used is secondary data. The analytical method used is multiple regression analysis, correlation coefficient $(r)$ and coefficient of determination ( $r 2)$, $t$-test and $f$-test. The results show that partially capital structure (DER) has a negative and insignificant effect on firm value, ( $P B V)$ while profitability (ROA) has a positive and insignificant effect on firm value (PBV). Simultaneously, capital structure (DER) and profitability have no significant effect on firm value $(P B V)$. Based on the results of the coefficient of determination of 0.36 , it means that the firm value $(P B V)$ is influenced by capital structure (DER) and profitability (ROA) by $36 \%$ and the remaining $64 \%$ is influenced by other factors not examined. The hypothesis in this study is accepted.

Keywords : capital structure, profitability, firm value

\section{PENDAHULUAN}

Kondisi perekonomian sekarang menciptakan persaingan yang sangat ketat antar suatu perusahaan. Persaingan tersebut akan memberikan dampak baik dan dampak buruk terhadap kinerja suatu perusahaan baik perusahaan yang berskala kecil sampai perusahaan berskala besar. Persaingan tersebut mendorong perusahaan selalu berusaha untuk mempertahankan dan meningkatkan nilai perusahaannya agar dapat terus bersaing dan mampu menciptakan keuntungan.

Tujuan utama sebuah perusahaan adalah meningkatkan kesejahteraan pemegang saham. Peningkatan kesejahteraan pemegang saham dapat dilihat dari nilai perusaahaan itu sendiri. Nilai perusahaan yang tinggi mengindikasikan bahwa kesejahteraan pemegang saham tinggi. Nilai perusahaan adalah salah satu hal yang dapat dijadikan 


\section{AkMen \\ Volume 18 Nomor 3 Desember 2021 \\ Hal. 310 - 320 \\ e-ISSN : 2621-4377 \& p-ISSN : 1829-8524 \\ Homepage : https///e-jurnal.nobel.acid/indexphp/akmen}

patokan untuk investor serta faktor yang menjadikan investor tertarik untuk menginvestasikan dananya dalam bentuk saham.

Ada beberapa faktor yang dapat mempengaruhi nilai perusahaan diantaranya adalah struktur modal dan profitabilitas. Struktur modal dan profitabilitas itu sendiri merupakan faktor yang diperhatikan oleh investor karena berkaitan dengan risiko dan pendapatan yang akan diterima oleh investor.

Menurut Husnan dan Pudjiastuti (2015), teori struktur modal menjelaskan kebijakan pendanaan perusahaan yang berkenan dengan hutang dan ekuitas digunakan untuk memaksimumkan nilai perusahaan. Perbandingan modal pinjaman dan modal sendiri haruslah tepat karena perbandingan tersebut akan berakibat langsung terhadap posisi keuangan.

Kebijakan hutang merupakan penentuan berapa besarnya hutang yang akan digunakan perusahaan dalam mendanai aktivanya yang ditunjukkan oleh rasio antara total hutang dengan total aktiva yang berhubungan dengan struktur modal. Kebijakan hutang termasuk kebijakan pendanaan perusahaan yang bersumber dari eksternal. Sebagian perusahaan menganggap bahwa penggunaan hutang dirasa lebih aman dari pada menerbitkan saham baru (Brigham dan Gapenski, 2006).

Profitabilitas adalah tingkat kemampuan perusahaan dalam menghasilkan keuntungan. Penilaian prestasi perusahaan dapat terlihat dari kemampuannya menghasilkan laba. Nilai perusahaan akan meningkat apabila profitabilitas tinggi, hal ini menunjukkan prospek perusahaan baik sehingga banyak investor yang akan merespon atau ikut berinvestasi. (Sujono dan Soebiantoro, 2007).

Kadek Aprianda dan Made Sadha Suardhika (2016) menemukan bahwa struktur modal berpengaruh negatif dan tidak signifikan terhadap nilai perusahaan sedangkan profitabilitas berpengaruh positif dan tidak signifikan terhadap nilai perusahaan. Dewa Ayu Intan Yoga Maha Dewi dan Gede Mertha Sudiarta (2017) menemukan bahwa profitabilitas berpengaruh positif dan signifikan terhadap nilai perusahaan. Selain itu, Bulan Oktrima (2017) menemukan hasil bahwa secara parsial profitabilitas dan struktur modal tidak berpengaruh terhadap nilai perusahaan.

Berdasarkan hasil penelitian sebelumnya, diperoleh riset karena adanya perbedaan penelitian sebelumnya mengenai pengaruh struktur modal dan profitabilitas terhadap nilai perusahaan. Sehingga hal ini yang menjadi permasalahan penelitian mengenai sturktur modal dan profitabilitas terhadap nilai perusahaan.

Menurut Sudana (2011), struktur modal (capital structure) berkaitan dengan pembelanjaan jangka panjang suatu perusahaan yang diukur dengan perbandingan hutang jangka panjang dan modal sendiri. Dengan kata lain, struktur modal adalah struktur pembiayaan dikurangi passiva lancer suatu perusahaan.

Fahmi (2015) menyatakan bahwa struktur modal merupakan gambaran dari bentuk proporsi finansial perusahaan yaitu antara modal yang dimiliki bersumber dari hutang jangka panjang (long-term liabilitites) dan modal sendiri (shareholders equity).

Terdapat beberapa teori tentang sturktur modal, diantaranya :

1. Pendekatan Tradisional 


\section{AkMen \\ Volume 18 Nomor 3 Desember 2021 \\ Hal. 310 - 320 \\ e-ISSN : 2621-4377 \& p-ISSN : 1829-8524 \\ Hbmepage: https//e-jurnal.nobel.acid/index.php/akmen}

Menurut Sawir (2015), penganut pendekatan ini berpendapat bahwa dalam keadaan pasar modal sempurna dan tidak ada pajak, struktur modal berpengaruh terhadap nilai perusahaan.

2. Teori Modigliani Miller

a. Teori MM Tanpa Pajak

Menurut MM struktur modal tidak relevan atau tidak mempengaruhi nilai perusahaan. Dalam Brigham dan Houston (2011), MM mengajukan beberapa asumsi untuk membangun teori mereka, yaitu :

1) Tidak terdapat agency cost,

2) Tidak ada pajak,

3) Investor dapat berhutang dengan tingkat suku bunga yang sama dengan perusahaan,

4) Investor mempunyai informasi yang sama seperti manajemen mengenai prospek perusahaan di masa depan,

5) Tidak ada biaya kebangkrutan,

6) Earning before interest and tax (EBIT) tidak dipengaruhi oleh penggunaan hutang,

7) Para investor adalah price-taker.

8) Jika terjadi kebangkrutan maka asset dapat dijual pada harga pasar (market value).

b. Teori MM dengan Pajak

Teori MM tanpa pajak dianggat tidak realistis dan kemudian MM memasukkan fakor pajak ke dalam teorinya. Pajak dibayarkan kepada pemerintah, yang berarti merupakan aliran kas keluar. Hutang bias digunakan untuk menghemat pajak, karena bunga bias dipakai sebagai pengurang pajak.

3. Teori Trade-Off

Menurut teori trade off yang dikemukakan Myers (1984), perusahaan akan berhutang sampai pada tingkat hutang tertentu, dimana penghematan pajak (tax shields) dari tambahan hutang sama dengan biaya kesulitan keuangan (financial distress). Biaya kesulitan adalah biaya kebangkrutan (bankcruptcy costs) atau reorganization dan biaya keagenan (agency costs) yang meningkat akibat dari turunnya kredibilitas suatu perusahaan.

4. Teori Pecking Order

Menurut Myers (1984), pecking order theory menyatakan bahwa perusahaan dengan tingkat profitabilitas yang tinggi justru tingkat hutangnya rendah, dikarenakan perusahaan yang profitabilitasnya tinggi memiliki sumber dana internal yang berlimpah. Dalam teori ini tidak terdapat struktur modal yang optimal.

Riyanto (2016) berpendapat bahwa faktor-faktor yang mempengaruhi struktur modal adalah :

1. Tingkat bunga

2. Stabilitas dari earning 
3. Susunan dari aktiva

4. Kadar risiko dari aktiva

5. Besarnya jumlah modal yang dibutuhkan

6. Keadaan pasar modal

7. Sifat manajemen

8. Besarnya suatu perusahaan.

Profitabilitas merupakan suatu rasio keuangan perusahaan yang menilai bagaimana kemampuan perusahaan menghasilkan laba. Menurut Sunyoto (2013), profitabilitas adalah kemampuan perusahaan untuk memperoleh keuntungan dari usahanya. Selain itu, Menurut Brigrham dan Houston (2013), profitabilitas adalah hasil akhir dari sejumlah kebijakan dan keputusan manajemen perusahaan.

Profitabilitas adalah ukuran sampai seberapa besar efektivitas manajemen dalam mengelola asset dan modal yang dimiliki perusahaan untuk menghasilkan laba dari aktivitas yang dilakukan perusahaan pada periode akuntansi tertentu, (Husnan, 2009).

Harahap (2015), mendefinisikan profitabilitas sebagai kemampuan perusahaan mendapatkan laba melalui semua kemampuan dan sumber daya yang ada seperti kegiatan penjualan, kas, modal, jumlah karyawan, jumlah cabang perusahaan dan lain sebagainya.

Nilai perusahaan merupakan salah satu hal yang digunakan investor untuk melihat tingkat keberhasilan perusahaan yang sering dikaitkan dengan harga saham. Harga saham mengindikasikan kinerja perusahaan dalam keadaan baik atau tidak. Perusahaan yang mempunyai harga saham yang tinggi meningkatkan kepercayaan pasar terhadap prospek perusahaan di masa yang akan datang.

Menurut Sartono (2010), nilai perusahaan adalah nilai jual sebuah perusahaan sebagai sebuah bisnis yang sedang beroperasi. Adanya kelebihan nilai jual atas nilai likuidasi adalah nilai dari organisasi manajemen yang menjalankan perusahaan itu. Selain itu, menurut Harmono (2017), nilai perusahaan adalah kinerja perusahaan yang dicerminkan oleh harga saham yang dibentuk oleh permintaan dan penawaran pasar modal yang merefleksikan penilaian masyarakat terhadap kinerja perusahaan. Menurut Gitman (2012), nilai perusahaan adalah nilai actual perlembar saham yang akan diterima apabila asset perusahaan dijual sesuai harga saham.

Pengukuran nilai perusahaan menurut Brigham dan Daves (2014) dalam rasio penilaian perusahaan terdiri dari :

1. Price earning ratio (PER), yang menggambarkan apresiasi pasar terhadap kemampuan perusahaan dalam menghasilkan laba

2. Price to book value (PBV), menggambarkan sebesara besar pasar menghargai nilai buku saham suatu perusahaan. Semakin tinggi PBV berarti pasar percaya akan prospek perusahaan tersebut.

3. Rasio tobin's yang membandingkan dua penilaian dari dua asset yang sama.

\section{Hubungan Struktur Modal dengan Nilai Perusahaan}

Menurut Sartono (2010), jika pendekatan Modigliani dan Miller (MM) dalam kondisi ada pajak penghasilan perusahaan, maka nilai perusahaan akan meningkat terus 
karena penggunaan utang yang semakin besar. Tetapi perlu diingat bahwa bila sekarang dari financial distress dan nilai sekarang adalah aegency cost dapat mengakibatkan menurunnya nilai perusahaan.

Menurut trade-off theory, jika struktur modal berada di bawah titik optimal maka setiap penambahan hutang akan meningkatkan nilai perusahaan. Sebaliknya, jika posisi struktur modal berada di atas titik optimal maka setiap penambahan utang akan menurunkan nilai perusahaan. Oleh karena itu, dengan asumsi bahwa sebelum struktur modal optimal tercapai, maka trade-off theory mengindikasikan bahwa adanya hubungan positif terhadap nilai perusahaan.

\section{Hubungan Profitabilitas dengan Nilai Perusahaan}

Menurut Husnan (2009), semakin baik tingkat pertumbuhan ptofitabilitas berarti prospek perusahaan di masa depan dinilai semakin baik juga, artinya semakin baik pula nilai perusahaan di mata investor. Apabila kemampuan perusahaan untuk menghasilkan laba meningkat, maka harga saham juga akan meningkat.

Selain itu, menurut Prihadi (2008), nilai perusahaan dapat dicapai melalui peningkatan kinerja keuangan perusahaan. Return on asset (ROA) mengukur tingkat laba terhadap asset yang digunakan dalam menghasilkan laba tersebut. Semakin tinggi ROA maka semakin efisien perusahaan tersebut menggunakan asetnya untuk menghasilkan laba (Fermadi, Makhdalena, dan Trisnawati, 2015).

Berdasarkan uraian diatas, maka yang menjadi tujuan dalam penelitian ini adalah untuk mengetahui pengaruh sturuktur modal dan profitabilitas terhadap nilai perusahaan. Adapun hipotesis dalam penelitian ini adalah:

H1 = diduga terdapat pengaruh antara struktur modal terhadap nilai perusahaan

$\mathrm{H} 2$ = diduga terdapat pengaruh antara profitabilitas terhadap nilai perusahaan

H3 = diduga terdapat pengaruh antara struktur modal dan profitabilitas terhadap nilai perusahaan

\section{METODE PENELITIAN}

\section{Jenis dan Sumber Data}

Adapun jenis data yang digunakan dalam penelitian ini adalah data kualitatif, yaitu data yang diperoleh dari perusahaan dalam bentuk informasi baik secara lisan maupun tertulis seperti gambaran singkat, struktur organisasi dan aktivitas usaha. Dan data kualitatif, yaitu data yang diperoleh dari perusahaan dalam bentuk angka seperti laporan keuangan perusahaan.

Sumber data yaitu data sekunder, data yang diperoleh dari dokumen perusahaan yang berupa laporan tertulis yang dibuat secara berkala seperti laporan keuangan.

\section{Variabel Penelitian}

Menurut Sugiyono (2016:58), variabel penelitian pada dasarnya adalah segala sesuatu yang berbentuk apa saja yang ditetapkan oleh peneliti untuk dipelajari sehingga diperoleh informasi tentang hal tersebut, kemudian ditarik kesimpulannya. Variabel 
merupakan indikator terpenting yang menentukan keberhasilan suatu penelitian karena variabel penelitian adalah objek penelitian atau titik perhatian dalam suatu penelitian. Adapun variabel dalam penelitian ini adalah struktur modal yang diproxy kan dengan Debt to Equity Ratio, Profitabilitas yang diproxykan dengan Return on Asset (ROA) terhadap Nilai perusahaan yang diproxykan dengan Price to Book Value (PBV) pada PT. Kalbe Farma, Tbk.

\section{Definisi Operasional dan Pengukurannya}

1. Strukrur modal yang diproxy kan dengan Debt to Equity Ratio (DER), menunjukkan seberapa besar perusahaan dibiayai oleh utang dan ekuitas .

Debt to Equity Ratio $=\frac{\text { Total Hutang }}{\text { Total Ekuitas }}$

2. Profitabilitas yang diproxy kan dengan Retutn on Assets (ROA), menunjukkan kemampuan total aset dalam menghasilkan keuntungan yang tersedia bagi pemegang saham.

Return on Assets $(\mathrm{ROA})=\frac{\text { Laba Bersih }}{\text { Total Aktiva }}$

3. Nilai perusahaan yang diproxykan dengan Price to Book Value (PBV), menunjukkan seberapa besar pasar menghargai nilai buku saham suatu perusahaan.

Price to Book Value $(\mathrm{PBV})=\frac{\text { Harga pasar perlembar saham }}{\text { Nilai buku per lembar saham }}$

\section{Metode Analisis}

Sugiyono (2013:11) menjelaskan bahwa penelitian asosiatif adalah penelitian yang bertujuan untuk hubungan antara dua variabel atau lebih. Dalam kaitannya dengan penelitian ini untuk mengetahui hubungan antara struktur modal dan profitabilitas terhadap nilai perusahaan. Peneliti menggunakan alat bantu software SPSS versi 23.

Teknik analisis data menggunakan analisis regresi berganda (untuk melihat hubungan negatif atau positif antara variabel $\mathrm{X}$ dan $\mathrm{Y}$ ), uji determinasi ( $\mathrm{r}^{2}$ ) (untuk menilai seberapa besar variasi independen menerangkan variabel dependen, uji korelasi (r) (untuk menunjukkan kuat/tidaknya hubungan linear antar dua variabel), serta uji-t dan uji-f (untuk menilai tingkat signifikansi hubungan dua variabel).

\section{HASIL PENELITIAN DAN PEMBAHASAN}

Analisis Regresi Linear Berganda

Tabel 1. Koefisien regresi

Coefficients $^{\mathrm{a}}$

\begin{tabular}{|c|c|c|c|c|c|c|}
\hline \multirow{2}{*}{\multicolumn{2}{|c|}{ Model }} & \multicolumn{2}{|c|}{ Unstandardized Coefficients } & $\begin{array}{l}\text { Standardized } \\
\text { Coefficients }\end{array}$ & \multirow[b]{2}{*}{$\mathrm{t}$} & \multirow[b]{2}{*}{ Sig. } \\
\hline & & B & Std. Error & Beta & & \\
\hline \multirow[t]{3}{*}{1} & (Constant) & 3.268 & 5.455 & & .599 & .561 \\
\hline & DER & -.375 & .222 & -.483 & -1.692 & .119 \\
\hline & ROA & .203 & .320 & .181 & .634 & .539 \\
\hline
\end{tabular}

a. Dependent Variable: PBV 
Sumber data diolah, 2021

Berdasarkan hasil SPSS di atas, diperoleh persamaan regresi $\mathrm{Y}=3,268-0,375 \mathrm{X} 1$ $+0,203 \mathrm{X} 2+\mathrm{e}$.

Nilai (constant) menunjukkan nilai sebesar 2,268 artinya jika nilai variabel independen (Debt to equity ratio dan return on assets) nol maka nilai variabel dependen (price to book value) sebesar 3,268 satuan.

Nilai $\beta 1=-0,375$ yang merupakan koefisien regresi dari variabel struktur modal yang diproxykan dengan DER menunjukkan tanda negatif yang berarti setiap kenaikan 1 satuan pada DER maka akan menurunkan nilai PBV sebesar 0,375 satuan.

Nilai $\beta 2=0,203$ yang merupakan koefisien regresi dari variabel profitabilitas yang diproxykan dengan ROA menunjukkan tanda positif yang berarti setiap kenaikan 1 satuan pada ROA maka akan menaikkan nilai PBV sebesar 0,203 satuan.

\section{Koefisien Korelasi dan Determinasi}

Tabel 2. Hasil koefisien korelasi dan determinasi

\begin{tabular}{|l|r|r|r|r|}
\hline Model & \multicolumn{1}{|c|}{ R } & R Square & Adjusted R Square & Std. Error of the Estimate \\
\hline 1 & $.600^{\mathrm{a}}$ & .360 & .243 & 2.16682 \\
\hline
\end{tabular}

a. Predictors: (Constant), ROA, DER

Sumber : data diolah, 2021

Berdasarkan hasil analisis diperoleh nilai koefisien korelasi $(r)=0,600$ sehigga dapat disimpulkan bahwa terdapat pengaruh yang cukup kuat antara struktur modal (DER) dan profitabilitas (ROA) terhadap nilai perusahaan (PBV) pada PT. Kalbe Farma, Tbk.

Hasil determinasi $\left(\mathrm{r}^{2}\right)$ sebesar 0,360 yang berarti bahwa struktur modal (DER) dan profitabilitas (ROA) mampu mempengaruhi nilai perusahaan (PBV) PT. Kalbe Farma, Tbk sebesar 36\% dan sisanya 64\% dipengaruhi oleh faktor lain yang tidak diteliti.

\section{Uji Hipotesis (Uji-t)}

Tabel 3. Hasil uji-t

Coefficients $^{\mathrm{a}}$

\begin{tabular}{|c|c|c|c|c|c|c|}
\hline \multirow{2}{*}{\multicolumn{2}{|c|}{ Model }} & \multicolumn{2}{|c|}{ Unstandardized Coefficients } & \multirow{2}{*}{$\begin{array}{c}\text { Standardized } \\
\text { Coefficients } \\
\text { Beta }\end{array}$} & \multirow[b]{2}{*}{$\mathrm{t}$} & \multirow[b]{2}{*}{ Sig. } \\
\hline & & $\mathrm{B}$ & Std. Error & & & \\
\hline \multirow[t]{3}{*}{1} & (Constant) & 3.268 & 5.455 & & .599 & .561 \\
\hline & DER & -.375 & .222 & -.483 & -1.692 & .119 \\
\hline & ROA & .203 & .320 & .181 & .634 & .539 \\
\hline
\end{tabular}

a. Dependent Variable: PBV

Sumber data diolah, 2021 
Hasil uji hipotesis (uji-t) diperoleh nilai thitung variabel X1 sebesar $-1,692<t_{\text {tabel }}$ 2,201 dengan nilai signifikansi sebesar 0,119>0,05 sehingga terima $\mathrm{H}_{0}$ dan tolak $\mathrm{H}_{\mathrm{a}}$. Sehingga dapat disimpulkan bahwa terdapat pengaruh yang tidak signifikan antara struktur modal (DER) terhadap nilai perusahaan (PBV) pada PT. Kalbe Farma, Tbk.

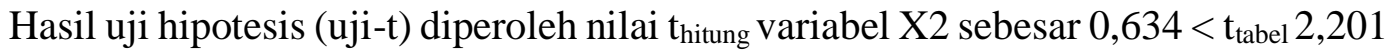
dengan nilai signifikansi sebesar 0,539>0,05 sehingga terima $\mathrm{H}_{0}$ dan tolak $\mathrm{H}_{\mathrm{a}}$. Sehingga dapat disimpulkan bahwa terdapat pengaruh yang tidak signifikan antara profitabilitas (ROA) terhadap nilai perusahaan (PBV) pada PT. Kalbe Farma, Tbk.

Uji Hipotesis (Uji-F)

Tabel 4. Hasil uji f

\begin{tabular}{|ll|r|r|r|r|r|}
\hline \multicolumn{1}{|c|}{ Model } & & Sum of Squares & df & Mean Square & F & Sig. \\
\hline 1 & Regression & 29.026 & 2 & 14.513 & 3.091 & $.086^{\mathrm{b}}$ \\
& Residual & 51.646 & 11 & 4.695 & & \\
& Total & 80.672 & 13 & & & \\
\hline
\end{tabular}

a. Dependent Variable: PBV

b. Predictors: (Constant), ROA, DER

Sumber : data diolah, 2021

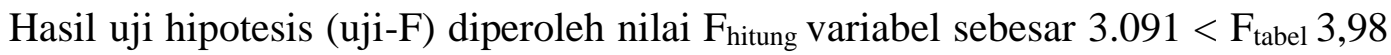
dengan nilai signifikansi sebesar 0,086 > 0,05 sehingga terima $\mathrm{H}_{0}$ dan tolak $\mathrm{H}_{3}$. Sehingga dapat disimpulkan bahwa secara serempak terdapat pengaruh yang tidak signifikan antara struktur modal (DER) dan profitabilitas (ROA) terhadap nilai perusahaan (PBV) pada PT. Kalbe Farma, Tbk.

\section{Pembahasan}

\section{Pengaruh Struktur Modal Terhadap Nilai Perusahaan}

Berdasarkan hasil penelitian di atas, struktur modal yang diproxykan dengan Debt to Equity Ratio (DER) berpengaruh negatif dan tidak signifikan terhadap nilai perusahaan yang diproxykan dengan Price to Book Value (PBV) pada PT. Kalbe Farma, Tbk. Hal tersebut menunjukkan bahwa setiap kenaikan rasio hutang yang dimiliki oleh perusahaan akan menurunkan nilai perusahaan. Hal tersebut sesuai dengan trade-off theory yang mengatakan jika posisi struktur modal berada di atas titik optimal maka setiap penambahan utang akan menurunkan nilai perusahaan.

Menurut Husnan dan Pudjiastuti (2015), teori struktur modal menjelaskan kebijakan pendanaan perusahaan yang berkenan dengan hutang dan ekuitas digunakan untuk memaksimumkan nilai perusahaan. Perbandingan modal pinjaman dan modal sendiri haruslah tepat karena perbandingan tersebut akan berakibat langsung terhadap posisi keuangan.

Jadi, perusahaan harus memperhatikan proporsi hutang dan modal yang dimiliki karena hal tersebut yang menjadi salah satu perhatian para calon investor yang akan 
menanamkan modalnya ke dalam perusahaan. Dan akan dilihat bagaimana stuktur modal tersebut akan mempengaruhi nilai perusahaan yang pada akhirnya akan menjadi keuntungan bagi para investor.

Hasil penelitian ini sejalan dengan hasil penelitian yang dilakukan oleh Kadek Aprianda dan Made Sadha Suardhika (2016) menemukan bahwa struktur modal berpengaruh negatif dan tidak signifikan terhadap nilai perusahaan.

\section{Pengaruh Profitabilitas Terhadap Nilai Perusahaan}

Berdasarkan hasil penelitian di atas, profitabilitas yang diproxykan dengan Return on Assets (ROA) berpengaruh positif tetapi tidak signifikan terhadap nilai perusahaan yang diproxykan dengan Price to Book Value (PBV) pada PT. Kalbe Farma, Tbk. Hal tersebut menunjukkan bahwa setiap kenaikan rasio profitabilitas yang didapatkan oleh perusahaan akan menaikkan nilai perusahaan. Hal tersebut didukung oleh pendapat yang dikemukanan oleh Husnan (2009), semakin baik tingkat pertumbuhan ptofitabilitas berarti prospek perusahaan di masa depan dinilai semakin baik juga, artinya semakin baik pula nilai perusahaan di mata investor. Apabila kemampuan perusahaan untuk menghasilkan laba meningkat, maka harga saham juga akan meningkat.

Profitabilitas adalah tingkat kemampuan perusahaan dalam menghasilkan keuntungan. Penilaian prestasi perusahaan dapat terlihat dari kemampuannya menghasilkan laba. Nilai perusahaan akan meningkat apabila profitabilitas tinggi, hal ini menunjukkan prospek perusahaan baik sehingga banyak investor yang akan merespon atau ikut berinvestasi. (Sujono dan Soebiantoro, 2007).

Hasil penelitian ini sejalan dengan penelitian yang telah dilakukan oleh Kadek Aprianda dan Made Sadha Suardhika (2016) yang menemukan bahwa profitabilitas berpengaruh positif dan tidak signifikan terhadap nilai perusahaan.

\section{KESIMPULAN}

Berdasarkan hasil penelitian dan pembahasan yang telah diuraikan sebelumnya, maka dapat disimpulkan sebagai berikut :

1. Secara parsial, struktur modal (DER) berpengaruh negatif dan tidak signifikan terhadap nilai perusahaan (PBV) pada PT. Kalbe Farma, Tbk. Sedangkan profitabilitas (ROA) berpengaruh positif dan tidak signifikan terhadap nilai perusahaan (PBV) pada PT. Kalbe Farma, Tbk.

2. Secara simultan, struktur modal (DER) dan profitabilitas (ROA) berpengaruh tidak signifikan terhadap nilai perusahaan (PBV) pada PT. Kalbe Farma, Tbk.

3. Hasil perhitungan koefisien korelasi (r) 0,60 menujukkan hubungan yang cukup kuat antara struktur modal, profitabilitas dan nilai perusahaan. Dan diperoleh nilai koefisien determinasi sebesar 0,360 atau 36\% nilai perusahaan (PBV) dipengaruhi oleh struktur modal (DER) dan profitabilitas (ROA) serta sisanya 64\% dipengaruhi faktor lain yang tidak diteliti.

\section{DAFTAR PUSTAKA}


Apriada, K., \& Suardikha, M. S. (2016). Pengaruh struktur kepemilikan saham, struktur modal dan profitabilitas pada nilai perusahaan. E-Jurnal Ekonomi dan Bisnis Universitas Udayana.

Brigham, E.F. \& Daves, P.R. (2014). Intermediate Financial Management. Cengange Learning.

Brigham, Eugene and L. Gapenski (2006). Intermediate Financial Management, $7^{\text {th }}$ Edition. Sea Harbor Drive : The Dryden Press.

Brigham, Eugene dan Houston Joel F. (2011). Dasar-dasar Manajemen Keuangan. Terjemahan. Edisi 10. Jakarta : Salemba Empat.

Dewi, D. A. I. Y. M., \& Sudiartha, G. M. (2017). Pengaruh Profitabilitas, Ukuran Perusahaan, Dan Pertumbuhan Aset Terhadap Struktur Modal Dan Nilai Perusahaan. E-jurnal Manajemen, 6(4), 2222-2252.

Fahmi, Irham. (2015). Pengantar Manajemen Keuangan Teori dan Soal Jawab. Bandung : Alfabeta.

Fermadi, H.L., Makhdalena dan Trisnawati, F. (2015). Pengaruh Kinerja Keuangan Terhadap Nilai Perusahaan. Jurnal Ekonomi, 1-13.

Gitman, J, Lawrence. (2012). Principle of Managerial Finance. 13 ${ }^{\text {th }}$ Edition. Pearson Education, Inc. United States.

Harahap, Sofyan Syafri. (2015). Analisis Kritis Atas Laporan Keuangan. Edisi 1-10. Jakarta : Rajawali Pers.

Harmono. (2017). Manajemen Keuangan Berbasis Balance Scorecard. Jakarta : Bumi.

Husnan, Suad. (2009). Dasar-dasar Teori Portofolio dan Analisis Sekuritas. Edisi empat. Yogyakarta : UPP AMP YKPN.

Husnan, Suad dan E. Pudjiastuti. (2015). Dasar-dasar Manajemen Keuangan, edisi ketujuh. Yogyakarta : UPP AMP YKPN.

Kasmir. (2014). Analisis Laporan Keuangan. Jakarta : Raja Grafindo Persada.

Myers, S. (1984). The capital structure Puzzle, Journal of Finance, Vol. 39, July, 1984.

Oktrima, B. (2017). Pengaruh Profitabilitas, Likuiditas, Dan Struktur Modal Terhadap Nilai Perusahaan. Jurnal Sekuritas, 1(1), 98-107.

Prihadi, T. (2008). Deteksi Cepat Kondisi Keuangan : 7 Analisis Rasio Keuangan (Ke1). Jakarta. PPM.

Riyanto, Bambang (2016) Dasar-dasar pembelajaran perusahaan cetakan kelimabelas, Yogyakarta:BPFE.

Sartono, R. Agus. (2010) Manajemen Keuangan Teori dan Perencanaan Keuangan Perencanaan. Jakarta .PT. Gramedia Pustaka Utama

Sawir, Agnes. (2015). Analisis Kinerja Keuangan dan Perencanaan Keuangan Perusahaan. Jakarta : PT. Gramedia Pustaka Utama.

Sudana, I Made. (2011). Manajemen Keuangan Teori dan Praktik. Surabaya : Airlangga.

Sugiyono. 2012. Metode Penelitian Pendidikan Pendekatan Kuantitatif, Kualitatif dan $R \& D$ Cetakan Ke-13. Bandung : ALFABETA

Sujono dan Soebiantoro, Ugy. (2007). Pengaruh Struktur Kepemilikan Saham, Leverage, Faktor Intern dan Faktor Ekstern Terhadap Nilai Perusahaan (Studi empirik pada 
perusahaan manufaktur dan non manufaktur di Bursa Efek Jakarta). Dalam Jurnal Manajemen dan Kewirausahaan, 9(1): h:43-47.

Suyoto, Danang. (2013). Analisis Laporan Keuangan. Jakarta : Salemba Empat. 